\title{
Indonesia Government Public Communication in the Covid-19 Pandemic Handling
}

\author{
Mukhammad Sahlan ${ }^{1 *}$ \\ ${ }^{1}$ Universitas Islam Negeri Sunan Kalijaga \\ Yogyakarta-Indonesia
}

Article Information

Submitted January 11, 2020

Revised January 25, 2021

Accepted February 15, 2021

Published April 01, 2021

\begin{abstract}
Since Covid-19 broke out in Indonesia, the public has monitored various government policies in dealing with these health disasters. However, policies run slowly; it gives rise to diverse public opinion. These multiple opinions become a form of communication between the government and society. However, the government does not fully capture people's views, so people feel they do not receive government policies' feedback. The purpose of this research is to find out how the Indonesian government's public communication is in dealing with the Covid-19 pandemic. The research used a descriptive qualitative method using data during Covid-19. This study explains how the debate of government and community communication occurs in the form of public opinion. Various forms of public opinion from adverse to positive states become message instruments aimed at the government. This instrument then forms communication in the form of action as a sense of moral panic due to the absence of a back answer to the opinion expressed. So, these opinions are only as answers and realized by society in phenomena.
\end{abstract}

Keywords: Public communication, Covid-19 Pandemic, Moral Panic, Government Policy.

\section{Introduction}

Confirmed cases of Covid-19 in Indonesia began in early 2020. Until early 2021, the addition of Covid-19 issues added to public panic. Until February 2021, positive sufferers of Covid-19 have reached one million people. On the other hand, the government has spoken many political dialectics in handling Covid-19 which hinders policies that they have implemented. It affects public opinion, which mass media supports. The mass media forms the power of virtual institutions, which then the movement manifests that. From a large amount of mass media information, it seems that the community has played a fast role in distributing aid for handling Covid outside government control. (Shereen et al., 2020)

Various assistance like masks, cash assistance, and primary food donations is a form of a movement born from insufficient opinions. Coupled with the community's moral panic that makes a group of new institutions created by social media move fast. However, what does this process look like, and how biased they think the government's role to be failing or slow in managing public opinion (Kurniawan et al., 2020). Many disagreements

\footnotetext{
*Author Correspondence: Mukhammad Sahlan, email: ahmadizudin25@yahoo.com, Jl. Marsda Adisucipto, Depok, Sleman, Yogyakarta-Indonesia 55281
}

Copyright (C) 2021 Mukhammad Sahlan 
within the government camp mean that communication between the government and the community tends to be not well connected. Society sees them as citizens who have rights as citizens who replace communities, ethnic and religious entities with mighty opinion power. The fact is that a nation or nationality, or citizenship does not have strong bargaining power (Aderson, 2020). To create positive communication with the government. It is very evident how the government's opinion management to accommodate publiwc opinions tends to be weak.

This paper describes the phenomenon of how the government communicates to summarize public opinion. Since 2015, social media has become a medium for connecting the public. We can use social media as a parameter to see people's views in assessing government policies to resolve the Covid-19 pandemic problem. Since Covid-19 broke out, various positive and negative opinions have developed rapidly. Some consider the government to be slow in determining Covid-19; some think they agree with government policies, and others have new views in response. These opinions then develop to have their community base. It is based on the same knowledge and is motivated by the status that forms the practice communities, as Etienne Wenger stated (Wenger, McDemort, \& Snyder, 2002). The organizations include a chain to convey their knowledge to the government in accelerating the handling of the Covid-19 problem.

The form of the public opinion communication movement to the government was then not matched by the existence of a social media community echoed by the government. As a result, many opinions have led to virtual and real movements to the absence of feedback (Pawardi, 2005). The researcher sees how the dynamics of view develop in society, and many of these opinions become a reality or just hope. If the government does not accommodate hopes or ideas adequately, it will form one-sided communication. Many things have resulted in a decreasing level of public trust in the government. This research is essential to do, especially since the pandemic also causes material losses for the community.

\section{Method}

This researcher conducted this research using descriptive qualitative methods. The researcher uses this method to make it easier to explain the phenomena in this study. Descriptive qualitative is a research method that creates descriptions of events systematically, factually, and accurately the facts, characteristics, and relationships between the phenomena under study (Meleong, 2001). We can use descriptive studies as a procedure for solving a phenomenon under investigation by describing or describing the current state of the subject or object of research (individuals, communities, community institutions, etc.) (Nawawi, 1997).

The writing of this study involves data on phenomena that have occurred through the mass media during Covid-19. This study uses existing literacy literature so it can read the primary data from the press in-depth. This study aims to answer public opinion problems that affect government policy in public opinion management.

The researcher uses some literature by equating academic needs that can explain government communication in handling 
pandemics. The government elaborated less on responses and statements regarding appropriate steps to deal with the pandemic. Simultaneously, the public is waiting for government policies in decision-making at the policymaker level to prepare the right strategy (Mubarok \& Insyiroh, 2020). In fact, until March 2020, the community saw the government's performance that was not ready to face the arrival of the Covid-19 outbreak. The government informed this unpreparedness in the national and regional media.

The existence of public opinion is due to the role of the media. According to Shoemaker and Reese, five factors form the hierarchy of influence in the media, individuals, media routines, media institutions, media organizations, and social systems. First, the individual element, the individual, is highly influenced by the media actors' background and characteristics (ethnicity, gender, social class, economic status) and the values of beliefs and race held by the media actors or users. Second, this element concerns how a theme is published. They publish it through the rhythm of work and the publication of the information. Currently, the mass media is involved with television and radio and has developed into online mass media. Twitter and Facebook are media that can turn opinion into a movement. Third, media institutions, when all opinions have become movements, media institutions will emerge as counterinstitutions in the realm of social media. In the end, the institution will form a social system with a bargaining position in the government's eyes. (Shoemaker \& Stephen, 1996). Fourth, media organizations talked about media organizations, including management of the media's goals and objectives. Fifth, social systems as social elements are interrelated with one another. According to Josep Ernst in McNair (2015), public space is a unique discursive space in which individuals gather to play a role in the form of reliable political power. It is the sphere of bourgeois politics that extends from what was once elitist to most people in modern democratic society. Today the power of the media establishes its role in realizing new political forces. Of course, in the end, it raises the pros and cons, a measure of public judgment, the formation of honest opinion and will invite responses.

\section{Discussion}

\section{Opinion from Controversial Explanation}

The Covid-19 phenomenon in the early days became one of the main wonders, which besides results in opinions, tended to moral panic. Cohen explained, "a key feature of contemporary society is the increasing involvement of social movements, identity politics, and victim advocates within moral panics. Involving a growing number of new moral entrepreneurs, including sociologists and feminists, and growing scope for such non-traditional moral entrepreneurs to gain media exposure" (David, Rohloff, Petley, \& Hughes, 2011). According to him, moral panic is considered one of the communication strategies and an act of reaction to realities that are not ideal or accepted by the public. The public realizes this strategy in the form of an action-directed opinion.

According to Lippman (Lippman 1995), opinion aspects include general affairs, general opinion, and public opinion. Groups are public opinions, Lippman explained; in analyzing the idea, public opinion analysts should introduce the triangular relationship 
between the scene, the human picture of the place, and the human response to the image itself independent of the scene's facts. Opinions occur because they do not realize the reactions, which are then accommodated by the internet media, creating a movement. The government should appropriately manage these opinions.

The government did not previously imagine the presence of Covid-19 in Indonesia. The government has not even investigated Covid-19 in Indonesia. At the time of its appearance in Indonesia, the government does not build a role model to handle Covid-19. So, it raises negative public opinion.

Some of the government's controversial explanations have become a confusing reference for the public. Especially international flights are still open to providing incentives for tourism industry doers. "Incentives for foreign tourists, the government, provides an additional allocation of 298.5 billion," said Coordinating Minister for Economic Affairs, Airlangga Hartarto at the Presidential Palace, Jakarta, Tuesday $(25 / 2 / 2020)$. Some of the government's controversial statements are shown in table 2 , summarized from the Kompas Daily (Hakim, 2020).

Walter Lippmann thinks the news in the mass media highly influenced individuals' image in the real world (1995). Since the Covid-19 outbreak, information regarding the spotlight of the government's controversial response has filled the entire mass media. The government has not explained the right step eagerly awaited by the government.

The compass survey results on March 24th, 2020, which followed 10,199 respondents expressed different opinions after the government's controversial explanation in early March.

Controversial explanations such as Minister Terawan's explanation regarding the use of masks and Luhut Panjaitan's explanation regarding Corona form a gap in public judgment in the form of opinion. The increasing number of patients means that the government is not fast and effective in dealing with its spread. It has resulted in the creation of a moral panic. This moral panic is what forms media routines and creates social institutions through the media, which end up in social organizations (Shoemaker \& Stephen, 1996)

When the government's explanation is deemed inadequate, other illustrations fill in the gaps, such as MUI's explanation of Preventing Corona Virus, MUI Calling for Increased Wudu, and Read Qunut Prayer (Gunada, 2020). Especially since the 1st, 2nd, and 3rd confirmed cases, the government has started to implement worship restrictions in worship places. It makes new opinions emerge and form a separate pros-cons, as explained by Josep Ernst in McNair (2015). Josep Ernst said that the public sphere is a unique discursive space where individuals gather to play a reliable political power. Josep Ernst considers it as a space that forms the power of the pros and cons itself.

Since March 30th, 2020, the social distancing policy has motivated various parties to move outside government control. The basis for the implementation of social distancing is an increase in the number of Corona positive patients by 1,414 people with a death ratio of 8.6 percent, according to National.kompas.com records. Theconversation.com (2020) explained that social distancing is a step to reduce the Covid 
Table 2.

A controversial statement issued by the Indonesian government in handling Covid-19

\begin{tabular}{|l|l|l|}
\hline \multicolumn{1}{|c|}{ Date } & \multicolumn{1}{|c|}{ Controversial Statement } & Who stated? \\
\hline $2 / 3 / 2020$ & $\begin{array}{l}\text { Even though we have the flu that usually happens to us, coughs } \\
\text { and colds have a higher death rate, but why can the Corona be } \\
\text { so excited }\end{array}$ & Terawan \\
\hline $2 / 3 / 2020$ & $\begin{array}{l}\text { Now, people will want to find a mask even though masks are for } \\
\text { people who are sick }\end{array}$ & Terawan \\
\hline $2 / 3 / 2020$ & $\begin{array}{l}\text { The important thing is to do healthy life. We do as usual, what is } \\
\text { different, nothing. Diphtheria is so great that we have nothing to } \\
\text { fear. Moreover, this is the Corona. }\end{array}$ & Terawan \\
\hline $4 / 3 / 2020$ & $\begin{array}{l}\text { Preventing Corona Virus, MUI Calls for More Wudu and Read } \\
\text { Qunut during prayers }\end{array}$ & MUI \\
\hline $22 / 4 / 2020$ & $\begin{array}{l}\text { "If it's not going home. It is returning home. Working in Jabo- } \\
\text { detabek, there are no jobs here, so they go home. Because their } \\
\text { children and wives are in the village, so they go home. }\end{array}$ & Jokowi \\
\hline $20 / 6 / 2020$ & $\begin{array}{l}\text { The title is in English; Corona is like your wife. Corona is like } \\
\text { your wife; when you want to marry, you think you can conquer } \\
\text { her, but you cannot dominate your wife after becoming your } \\
\text { wife. }\end{array}$ & $\begin{array}{l}\text { Luhut Panjai- } \\
\text { tan }\end{array}$ \\
\hline $\begin{array}{l}\text { "If not (there are findings of the Coronavirus), we should be } \\
\text { grateful, not questioned. That is what I do not understand; we } \\
\text { should be thankful that the Almighty still blesses us. }\end{array}$ & Terawan \\
\hline
\end{tabular}
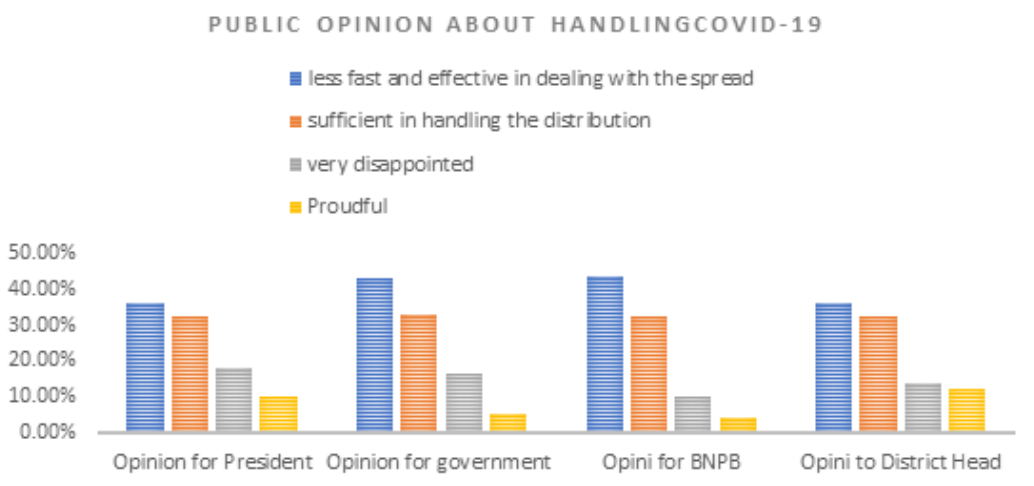

Figure 1.

Public opinion about the handling of Covid-19 by the Government

pandemic's impact by creating a distance between individuals as long as 1 meter. That means there are no restrictions on going out of the house, only restrictions on space. Meanwhile, the policy for work from home starts after April 3rd, 2020, and the second phase on May 14th, 2020. These appearances spawned new opinions, which then formed new solidarity movements outside the government's control.

This limitation is not in balance condition with solutions and government guarantees, so various opinions appear and develop quickly on social media. Social distancing, which 
affects the home activity's work, is interpreted as a mass homecoming movement. It has resulted in the acceleration of the spread of the Covid-19 virus in Indonesia. This action is a practice called Cohen's moral panic, which creates a new chaotic situation due to opinion to get social security when they enact the social distancing. (David, Rohloff, Petley, \& Hughes, 2011).

\section{Opinion and Formation of Solidarity Actions}

Individuals who have wishes conveyed through opinions are then channeled through various social media to get feedback. Lippman (1995:26) states that the expansion of view to become a movement based on social organizations has a separate role, especially in handling the Covid-19 outbreak outside the government. However, the government does not have a similar role model that is closer to society. People who do not get a chance in social organizations formed by social media tend to lead to Moral Panic. Moral panic is a panic that is excessive and propagated to produce communal terror. The form is social security through returning home for migrants in big cities. Ministry of Village data shows 805,479 people who have migrated back to their villages. (Tim Covid-19 IDAI, 2020) They previously lived-in cities choosing to return to villages for social security.

The emergence of Moral panic is caused by a definite vacuum of time, while society needs certainty in determining the daily economy. From here arose many movements, including returning to the village and going home. The phenomenon of going home and returning to hometown is something that contradicts the social distancing and Works from Home policies. For those who work as factory workers, work from home and social distancing are just a discourse. Those who experienced layoffs then expressed their opinions, but this was not accommodated and only manifested by the act of returning to their hometown and going home. (Kannan et al., 2020). Not only returning home, but they are implementing independent lockdown even in several areas without the government's permission. Not to mention the panic buying that overshadows the public as an act of moral panic. The absence of an information delivery system and public opinion forum has made individuals form a joint movement to realize their individual opinions. In the description of the existing timeline, moral panic appears, as seen in Figure 2.

On March 2nd, 2020, when the positive patient was confirmed, the government had not taken further steps until March 11th, 2020. There was a 9-day pause of public confusion, pauses that led to criticism along with the emergence of controversial opinions on March 4th, 2020. On March 30th, the government announced the ban on going home and going home. Of course, this point provokes an individual argument. On April 4-8, layoffs began to occur in the PSBB and $\mathrm{WFH}$ policies. At this stage, the media have started to act as a tool for frying news. It is called the media routine, which then forms media organizations, media institutions, and social organizations in homecoming and returning home actions. Besides homecoming, there is an independent lockdown movement due to influence theory (Shoemaker \& Stephen, 1996). At the end of April to early May, the new policy was announced and then realized in June. Some of the realizations of these policies are not by expectations and, in their completion, are not by reality. 
Several online media discuss the moral panic phenomenon that shapes opinions. The summary of this phenomenon is inseparable from the five levels that influence birth opinion-for example, tirto. Id wrote of lockdown activities in villages in Pakem Sleman, Yogyakarta starts implementing incomplete information cause panic buying. Dicky analyzes the behavior of the Indonesian people in the Republika.co.id news.

"The government as an influencer needs to show that evidence (sufficient logistical needs) and show it to the public and ensure a safe supply."

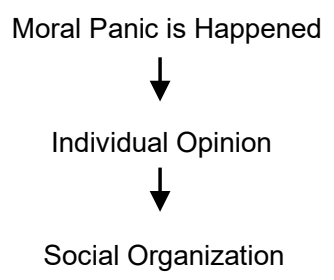

Figure 2.

Timeline of moral panic in the society

lockdowns. They are worried about Corona; there are no positive Corona cases in their town (Syambudi, 2020 ).

"Chairman of RW 24 Dusun Cepet, Purwobinangun Village, Pakem Suwarso, said the access road to the village had been closed since Friday (27/3/2020) to anticipate the spread of the Coronavirus. "This morning, the road had started to be blocked [not allowed to pass in and out of the village]. After Friday, we will give a lockdown writing," said Suwarso to Tirto, Friday. "This is to anticipate the immigrants. Those already inside are not [allowed] to go in and out," he added."

Panic buying has hit parts of Indonesia and many places in the world. As a result, many raw materials have increased in price. From a search on Republika.co.id, the
A video became viral on social media using personal protective equipment (PPE) in a hazmat suit at the Gandaria City shopping center, South Jakarta. The visitor was also reprimanded by the mall security officer and asked to take off the shirt but did not want to. (Kompas.com March 30th, 2020). The importance of a forum for conveying aspirations in Indonesia's form of opinions is very much needed. If not, there will be many dynamic phenomena that are more complex and difficult to control by the government. The government's lack of speed in managing public opinion impacts the extent of the Covid-19 outbreak area. It is what is called a movement pattern that begins with a 
medium. In the opinion scale aspect, Lippman said that action in these three phenomena falls into the category of public opinion. This general opinion has formed its own media institution and is ready to be translated into new sensations.

This movement is a form of minimal opinion feedback from the government in building communication at the public level. People who wait for policies because of reciprocal communication fail to be accepted, thus making this opinion grow even wilder. Finally, the community takes actions as discussed to create a unidirectional phenomenon of public opinion (Gruning \& Hunt, 1984).

\section{Government Public Communication Policy Practices}

Government policies that are considered slow in handling Covid-19 by the community have had quite a strong impact, the increasing number of Covid-19 patients in Indonesia. As of September 2020, there were 392,000 cases, 322,000 confirmed cured, and 13,512 died (Covid-19 Surveillance Group, 2020). This record has its impact on the Indonesian people, especially those who choose to stay at home. The development of government policies is undoubtedly more inclined towards strengthening the economy of the people currently.

Some of the current policies are pro to the people, but many of these policies are not in reality. Since public opinions moved various actions at the start of the pandemic, currently, public opinion is focused on approaches to handle Covid-19, some of which are not as expected. From the beginning of the Covid-19 allowance for affected families, UMKM assistance, free electricity, pre-employment card allowances, and essential food assistance did not escape the community evaluation.

On April 1st, 2020, the government issued a policy to deal with the impact of Covid-19. As shown in table 3 (Dhyaksa, 2020), eleven policy points that were later issued were reevaluated by the community.

Policies that are not by public opinion are in $3,4,5$ and 8 . Policy point 3 , the state will also increase the number of primary food card recipients from the previous 15.2 million recipients to 20 million recipients, is considered unevenly realized. Meanwhile, point 4 related to electricity rates has become a public complaint. Point 5 regarding preemployment benefits, the government does not disburse on time. Point 8 , regarding KUR relief, is not felt by people who have loans other than KUR.

Not to mention the case of late disbursement of pre-work, which the government realized only in July. This phenomenon must be a review for the government, especially using social media as a means of public communication that is more effective in accommodating all developing opinions (Indrawan, 2017). It can take various forms, one of which is a citizen media channel that can accommodate ideas from short articles and similar articles.

Until now, the presence of public opinion is still rolling, especially considering that the passing of Job Creation Law these days. Society has carried out Law intensively's violent protests, adding to the government's long list ignoring In the end, many hopes and realities are not in line. Expectations and reality are inversely related. The negative impact is a growing public distrust of the government and its policies. 
Table 3.

Government Policy in Tackling the Covid-19 Pandemic

\begin{tabular}{|c|c|c|}
\hline No & Policy & Explanation \\
\hline 1. & $\begin{array}{l}\text { Support for the } \\
\text { Health Sector }\end{array}$ & $\begin{array}{l}\text { The government has budgeted Rp. Seventy-five trillion to protect medi- } \\
\text { cal personnel, such as the procurement of personal protective equipment } \\
\text { (PPE). Also, the government provides incentives for doctors, compensa- } \\
\text { tion for the death of medical personnel of Rp. } 300 \text { million. }\end{array}$ \\
\hline 2. & $\begin{array}{l}\text { Monthly Medical Per- } \\
\text { sonnel Incentives }\end{array}$ & $\begin{array}{l}\text { In addition to providing death benefits to medical devices, the govern- } \\
\text { ment will also offer incentives to specialist doctors of IDR } 15 \text { million / } \\
\text { month, doctor IDR } 10 \text { million / month, nurses IDR } 7.5 \text { million / month, } \\
\text { and other medical personnel IDR } 5 \text { million / month. }\end{array}$ \\
\hline 3. & Social Protection & $\begin{array}{l}\text { PKH families [Program Keluarga Harapan] increased from } 9.2 \text { million } \\
\text { families to } 10 \text { million recipient families. The state will also increase the } \\
\text { number of primary food card recipients from the previous } 15.2 \text { million } \\
\text { recipients to } 20 \text { million recipients. Assistance to card recipients also in- } \\
\text { creased by around } 33 \text { percent, from IDR } 150,000 \text { to IDR } 200,000 \text {. }\end{array}$ \\
\hline 4. & Electricity Rates & $\begin{array}{l}\text { For } 450 \text { VA electricity customers, around } 24 \text { million customers will be } \\
\text { free for the next three months, April, May, and June } 2020.900 \text { VA electric- } \\
\text { ity customers will get relief in the form of a } 50 \text { percent discount during } \\
\text { the same period. Currently, the number of customers using } 900 \text { VA elec- } \\
\text { tricity is around } 7 \text { million customers. } \\
\text { The government also increased the housing incentive for low-income } \\
\text { people (MBR) to } 175,000 \text {. The government also provides logistical sup- } \\
\text { port for primary food and basic needs with a budget allocation of IDR } 25 \\
\text { trillion. }\end{array}$ \\
\hline 5. & $\begin{array}{l}\text { Increase Pre-Em- } \\
\text { ployment Card } \\
\text { Budget }\end{array}$ & $\begin{array}{l}\text { The pre-work card budget, from Rp. } 10 \text { trillion, was increased to Rp. } 20 \\
\text { trillion. Meanwhile, the number of beneficiaries was set at } 5.6 \text { million } \\
\text { people and prioritized informal and micro and small business actors. }\end{array}$ \\
\hline 6. & Economic Recovery & $\begin{array}{l}\text { The government will pay PPh } 21 \text { or income tax for workers in the manu- } \\
\text { facturing sector with a maximum income of IDR } 200 \text { million in one year. } \\
\text { The government also exempts import PPh for } 19 \text { specific sectors. It tar- } \\
\text { gets Taxpayers for the Ease of Import for Export Purposes (KITE) and } \\
\text { Taxpayers for Small and Medium Industry KITE. The government also } \\
\text { reduces PPH } 25 \text { by } 30 \text { percent for specific KITE and Small and Medium } \\
\text { Industry KITE Taxpayers sectors. The corporate income tax rate has also } \\
\text { been reduced to } 22 \text { percent for } 2020 \text { and } 2021 \text { and } 20 \text { percent starting } \\
2022 \text {. }\end{array}$ \\
\hline 7. & $\begin{array}{l}\text { Anticipate the APBN } \\
\text { Deficit }\end{array}$ & $\begin{array}{l}\text { A Perppu was issued to anticipate the APBN deficit, which is estimated } \\
\text { to reach } 5.07 \text { percent. Therefore, the government needs relaxation of the } \\
\text { APBN deficit policy of above } 3 \text { percent. }\end{array}$ \\
\hline 8. & $\begin{array}{l}\text { KUR customers get } \\
\text { installment relief }\end{array}$ & $\begin{array}{l}\text { Postponement of principal and interest payments for all KUR [people's } \\
\text { business credit] schemes affected by Covid-19 for six months }\end{array}$ \\
\hline 9. & Non-Fiscal Sector & $\begin{array}{l}\text { Non-fiscal policies such as simplifying Lartas for exports, simplifying Lar- } \\
\text { tas imports, accelerating export-import processing services through the } \\
\text { National Logistic Ecosystem }\end{array}$ \\
\hline
\end{tabular}




\begin{tabular}{|c|l|l|}
\hline 10. & $\begin{array}{l}\text { Expenditures Refo- } \\
\text { cusing and Reloca- } \\
\text { tion }\end{array}$ & $\begin{array}{l}\text { The government maintains prudent fiscal management by refocusing } \\
\text { and reallocating spending for handling Covid-19, making expenditure } \\
\text { savings (K / L and TKDD expenditures) that are not prioritized according } \\
\text { to changes in conditions in 2020 - resulting in savings of IDR 190 trillion } \\
\text { and including reallocation. Reserves of IDR 54.6 trillion. }\end{array}$ \\
\hline 11. & Prepare PERPU & $\begin{array}{l}\text { PERPU also anticipating the possibility of a deficit which the expectation } \\
\text { is to reach 5.07 percent }\end{array}$ \\
\hline
\end{tabular}

\section{Conclusion}

The handling of the Covid-19 pandemic in Indonesia creates its own discursive space that the government is not sensible. Many opinions came out of various groups in the area, creating dynamics outside the government's control. It occurred due to the slow pace of the government in determining pandemic management policies. At the beginning of handling Covid-19, the government only issued an opinion, not a policy statement. As a result, people are confused and make their own decisions in various ways, including independent lockdowns. Things like this create an opinion that the government is slow in handling the Covid-19 case. The rest of this communication, unidirectional, creates various moral panic forms, creating new problems.

Unbalanced communication resulted in the level of distrust towards the government getting smaller. As a result, a new debate appears in unique spaces that develop out of control. The emergence of community groups carrying the Khilafah's slogan marked the form of these movements. Two-way communication between the community and the government is urgent to build openness. If we had well-established two-way communication, we hoped that public trust in the government would also increase.

\section{References}

Anderson, B. (2008). Imagined Community: Komunitas-Komunitas terbayang. Yogyakarta : Insist Pers.

Covid-19 Surveillance Group. (2020). Characteristics of Covid-19 patients dying in Italy Report based on available data on March 20th, 2020. Covid-19 Surveillance Group.

David, M., Rohloff, A., Petley, J., \& Hughes, J. (2011). The idea of moral panic - ten dimensions of the dispute. Crime Media Culture, 1-15.

Dhyaksa, Andya. (2020). 11 Poin Penting Kebijakan Ekonomi Jokowi Menghadapi Wabah Corona. Ekonomi Bisnis.com accessed in 11 Poin Penting Kebijakan Ekonomi Jokowi Menghadapi Wabah Corona - Ekonomi Bisnis.com

Gunada, Reza \& Yasir, Muhammad. (2020). Cegah Virus Corona, MUI Serukan Perbanyak Wudu dan Baca Qunut Saat Salat. Suara.com accessed in Cegah Virus Corona, MUI Serukan Perbanyak Wudu dan Baca Qunut saat Salat (suara.com)

Gruning, J., \& Hunt, T. (1984). Managing Public Relations. Fort Wort: Holt Reinhart and Wiston .

Hakim, Rakhmat Nur. (2020). Kilas Balik

6 Bulan Covid-19: Pernyataan Kontroversial Pejabat soal Virus Corona. 
Kompas.com. from Kilas Balik 6 Bulan Covid-19: Pernyataan Kontroversial Pejabat soal Virus Corona... page all Kompas.com

Indrawan, R. M. (2017). Dampak Komunikasi Politik dan Opini Publik Terhadap Perilaku Masyarakat. WACANA Scientific Journal of Communication Scienceli, 171179.

Kannan, S., Shaik Syed Ali, P., Sheeza, A., \& Hemalatha, K. (2020). Covid-19 (Novel Coronavirus 2019) - recent trends. European Review for Medical and Pharmacological Sciences. https://doi. org/10.26355/eurrev_202002_20378

Kurniawan, H. H., Salahuddin, A. M., Muslim, \& Sri, N. (2020). Konsep Kebijakan Strategis dalam Menangani Eksternalitas Ekonomi dari Covid - 19 pada Masyarakat Rentan di Indonesia. Indonesian Journal of Social Sciences and Humanities,.

Lippman, w. (1995). Public Opinion. Chicago: Transaction.

McNair, B. (2015). Pengantar Komunikasi Politik. Bandung: Nusa Media .

Meleong, L. J. (2001). Metode Penelitian Kualitatif. Bandung: Remaja Rosdakarya.

Mubarok, S., \& Insyiroh, I. M. (2020). Teknologi Kecedasan Buatan, Big Data Analysis, dan Internet of Things : Potensi dan Peranaran dalam Penanganan Covid-19 di Indonesia . Journal of Indonesian Population, 109-114.

Nawawi, H. (1997). Metode Penelitian Bidang Sosial. Yogyakarta: Gadjah Mada University Press.

Perceptions, R., Tyler, I., Slater, T., Organization, W. H., Ramaci, T., Barattucci, M., Ledda, C., Rapisarda, V., Nc, C., Saxena, S.,
Berger, B. E., Ferrans, C. E., Lashley, F. R., Choudhry, S., Burchard, E., Tedman, S., Thornton, E., Baker, G., Whiteneck, G. G., Jagelman, D. G. (2020). Current Issues in the Study of Social Stigma. Qualitative Health Research.

Pawardi, R. (2005). Studi Pemanfaatan Ruang Publik pada Komentar "Opini Anda" di RRI Pontianak. Mediator Vol. 6, 191-204.

Shereen, M. A., Khan, S., Kazmi, A., Bashir, N., \& Siddique, R. (2020). Covid-19 infection: Origin, transmission, and characteristics of human coronaviruses. In Journal of Advanced Research. https://doi. org/10.1016/j.jare.2020.03.005

Shoemaker, P., \& Stephen, R. (1996). Mediating the Message: Theories of Influences on Mass Media Content. New York: Longman Ltd.

Syambudi, I. ( 2020 ). Lockdown Mandiri ala Jogja: Di Tolak Pemerintah, diinginkan Warga. Jakarta: Tirto.id.

Tim Covid-19 IDAI. (2020). Protokol Tatalaksana Covid-19. 1.

Wenger, E., McDemort, R., \& Snyder, W. (2002). Cultivating Communities of Practice: A Guide To Managing Knowledge. Massachusetts: Harvard Business School Press.

Yasmin, A. A. (2020). Apa itu social distancing dan kenapa ini cara terbaik untuk melawan penyebaran Covid-19. Jakarta: theconversation.com. 